University of Puget Sound

Sound Ideas

All Faculty Scholarship

Faculty Scholarship

$1-1-1980$

\title{
The Cloak of Anonymity and "The Prophecy of John of Bridlington"
}

Michael Curley

University of Puget Sound, curley@pugetsound.edu

Follow this and additional works at: http://soundideas.pugetsound.edu/faculty_pubs

\section{Citation}

Curley, Michael. 1980. "The Cloak of Anonymity and the 'Prophecy of John of Bridlington'." Modern Philology 77(4): 361-369.

This Article is brought to you for free and open access by the Faculty Scholarship at Sound Ideas. It has been accepted for inclusion in All Faculty Scholarship by an authorized administrator of Sound Ideas. For more information, please contact soundideas@pugetsound.edu. 
The Cloak of Anonymity and "The Prophecy of John of Bridlington" Author(s): Michael J. Curley

Source: Modern Philology, Vol. 77, No. 4 (May, 1980), pp. 361-369

Published by: The University of Chicago Press

Stable URL: http://www.jstor.org/stable/437589

Accessed: $13 / 10 / 2014$ 18:25

Your use of the JSTOR archive indicates your acceptance of the Terms \& Conditions of Use, available at http://www.jstor.org/page/info/about/policies/terms.jsp

JSTOR is a not-for-profit service that helps scholars, researchers, and students discover, use, and build upon a wide range of content in a trusted digital archive. We use information technology and tools to increase productivity and facilitate new forms of scholarship. For more information about JSTOR, please contact support@ jstor.org. 


\title{
The Cloak of Anonymity and The Prophecy of John of Bridlington
}

\author{
Michael J. Curley
}

The Prophecy of John of Bridlington consists of an anonymous Latin poem of some 600 lines in leonine hexameters and a prolix Latin prose commentary dedicated to the young Humphrey of Bohun and introducing the poem as the work of a certain canon regular. Internal evidence suggests that the commentary was written shortly after the poetry, between November 1362 and April 1364. The composite work is a good example of the belligerent jingoism and moral frustration prevalent among certain learned Englishmen during the waning rule of the aged Edward III. Pretending to antedate the events foreseen, The Prophecy of John of Bridlington is for the most part simply a historical retrospect of English affairs beginning during the reign of Edward II. Approximately the last eight of twenty-nine chapters, however, are truly "prophetic," envisioning future events down to the year 1405 and slightly thereafter.

Although the existence of some thirty-seven manuscripts of our prophecy attests to its popularity, scribes, chroniclers, bibliophiles, and bibliographers have long disagreed on the identity of its author; so inflammatory were its contents that at least one friar of supposed conspiratorial disposition was hanged for quoting its libelous stanzas, and one English king was provoked by it sufficiently to brand its interpreters "fatui et idiotae." 1 It is no wonder, therefore, that the true author of The Prophecy of John of Bridlington chose to remain unknown and that scholars of political prophecy have attempted to discern his identity. ${ }^{2}$

With the sole exception of University of Chicago MS 697, whose colophon dating the manuscript in the year 1377 is to be seriously doubted,$^{3}$ the earliest surviving manuscripts of The Prophecy of John of Bridlington are silent on the question of authorship. In what are probably the four earliest copies of the work, all dating from the late fourteenth or early fifteenth century-British Museum MS Cotton Domitian A IX and Bodleian MSS Digby 89, Bodley 851, and Ashmolean

1/For the 1402 conspiracy of the friar minor from Leicester and Henry IV's reaction to his quoting Bridlington "iuxta imaginationem suam" as the authority which proved that Richard was still alive, see Eulogium Historiarum sive Temporis, ed. Frank S. Haydon (Rolls Ser. 9-3; London, 1863), pp. 391-94; E. F. Jacob, The Fifteenth Century (Oxford, 1961), p. 28; Isobel D. Thornley, "Treason by Words in the Fifteenth Century." English Historical Review 32 (1917): 556-61. esp. pp. 560-61.

2/Among the most important of those who have addressed themselves to the question of authorship, see Thomas Wright, ed., Political Poems and Songs Relating to English History . . from the Accession of Edward III to Richard III (London, 1859-61), 1:xxix, 123; M. R. James, "The Catalogue of the Library of Augustinian Friars at York. Now First Edited from the Manuscript at Trinity College Dublin." Fasciculus Joanni Willis Clark Dicatus (Cambridge, 1909), p. 12; Rupert Taylor, The Political Prophecy in England (New York, 1911), p. 52; Sister Helen M. Peck. "The Prophecy of John Bridlington" (Ph.D. diss., University of Chicago, 1930), pp. 22-26; Aubrey Gwynn. The English Austin Friars in the Time of Wyclif (Oxford, 1940), char $\rightarrow$ Paul Meyvaert, "John Erghome and the Vaticinium Roberti Bridlington," Speculum 41 (1966): 656-64.

3/The late Arthur Heiserman informed me that the University of Chicago MS 697, though bearing a colophon on fol. 61 dating the manuscript at 1377, is copied on French paper whose final gatherings carry a watermark which can be dated ca. 1450. Thomas Hearne examined this manuscript in 1725 and concluded that it was written in the reign of Henry IV (1399-1413). See Remarks and Collections of Thomas Hearne, ed. H. E. Salter (Oxford, 1915), 10:282. Malcolm Parkes of Keble College, Oxford, who kindly examined the handwriting of MS 697 for me, reports that the manuscript was copied in all probability during the third quarter of the fifteenth century. A heading on fol. 91v of MS 697 identifies the author as Johannis de Brydlyngton.

(C) 1980 by The University of Chicago. 0026-8232/80/7704-0001\$01.02 
1804 there is only vague attribution of authorship. The first two of these manuscripts preserve the commentary in which the author is said to be a certain canon regular according to popular opinion. The last two copies do not venture beyond the neutral "prophecia cuiusdam" and "versus cuiusdam laici," respectively. Fourteen other scribes and copyists through the next 300 years followed the early anonymous tradition. ${ }^{4}$ There is evidence, however, from some early-fifteenthcentury manuscripts that some of the scribes associated the prophecy with the Augustinian monastery at Bridlington, ${ }^{5}$ and it should be noted that this attribution, too, exerted a strong and lasting impression on later copyists, ten of whose manuscripts have survived with the heading "Bridlington" or "secundum Bridlington," and so forth. ${ }^{6}$ However, only in manuscripts executed around the midfifteenth century and after do scribes affix the particular names of John ${ }^{7}$ and Robert of Bridlington ${ }^{8}$ to their copies of the prophecy, for reasons which I shall suggest later.

In summary, a review of the manuscript testimony seems to indicate that, of the two earliest traditions regarding the authorship of the prophecy, one left the piece anony mous, the other proclaimed a canon regular as the author. Association of the work with "Bridlington" was an early-fifteenth-century phenomenon, but a later tradition arose toward the mid-fifteenth century attributing the piece to John or Robert of Bridlington.

Before considering the historical circumstances out of which these manuscripts' attributions arise, two caveats should be noted. Paul Meyvaert has pointed out two manuscripts, British Museum MSS Cotton Vespasian E VII and Arundel 66, bearing "Bridlington" headings, but with seemingly misplaced colophons later proclaiming Robert the Scribe to be the author of our prophecy. ${ }^{9}$ Such evidence might show that to some scribes of the mid-fifteenth century "Bridlington" may have been synonymous with Robertus Scriba (Robert of Bridlington). Robert's name, for example, is found in the explicit attached to two copies of the English translation of certain lines of the Latin prophecy in British Museum MSS Lansdowne 122, folio 45 verso and Additional 24,848, folio 13, while their corresponding Latin texts bear no indication of authorship. These two copies, however, are certainly derived from the same exemplar, now lost. The situation is further complicated by later owners and readers, dissatisfied with

4/Cambridge University MSS Additional 3392 and Kk.1.5(D) no. 4; Trinity College, Dublin MSS B.1.37 and B.2.7; British Museum MSS Lansdowne 122 and Additional 40,015, Royal 8C XVII, Cotton Titus D XII, Additional 24,842; Corpus Christi College, Cambridge MS 267; Westminster MS CA 27; Bibliothèque National. Paris MS Fonds Latin 15082; Bodleian MSS Rawlinson D 225 and D 366 (Thomas Hearne's holograph and our most recent copy of the prophecy, dated May 30, 1734).

5/Cambridge University MS Kk.6.16; Edinburgh University MS 181; British Museum MS Harley 3908; Society of Antiquaries of London MS 47.

6/Bodleian MSS Digby 186, Bodley 648, Hatton 56; British Museum MSS Arundel 66, Cotton Vespasian E VII. Harley 6148; the National Library of Wales MS Llanstephan 196; Gonville-Caius College, Cambridge MS 249; Trinity College, Dublin MS 516; Tours MS 520. The last two MSS indicate that the author was a prior at Bridlington, as were both John and Robert of Bridlington.

7/MS Bodley 487; British Museum MS Cotton Cleopatra C IV; University of Chicago MS 697.

8/MS Bodley 623 and Ashmolean Rolls 26.

9/Meyvaert, pp. 659-60. It should be noted that accepting Meyvaert's misplaced-colophon theory requires a certain leap of faith on the part of the mildly cautious palaeographer in the absence of concrete proof that the colophons do not belong precisely where the scribes place them and have nothing to do with the earlier "Bridlington" entries in Cotton Vespasian E VII and Arundel 66. 
scribal silence in regard to authorship, who scribble now the name of John of Bridlington, ${ }^{10}$ now "Bridlington," 11 in their originally anonymous versions of the prophecy.

None of the four manuscripts accompanied by the commentary ${ }^{12}$ originally associated the work with a specific author or place, since the commentary itself identifies the prophet merely as a canon regular according to popular opinion. In accord with the commentary tradition is the earliest contemporary reference to the prophecy in the catalog of books belonging to the Augustinian library at York. The catalog was drawn up in 1372 and contains three entries referring to our prophecy as: "versus cuiusdam canonici de actubus [sic] anglie," "prophetia canonici,febribus," and "Expositio versuum febribus infectus." 13 There can be little doubt that the "Expositio" is the commentary as we now possess it; whether the attribution of the prophecy to a certain canon regular originated in the commentary or was absorbed into it from manuscripts independent of the commentary (such as the other two listed in the York catalog) is impossible to determine.

That the prophecy became connected with the Yorkshire Augustinian priory at Bridlington is not surprising. Significantly, ca. 1377 the verses of the prophecy were quoted by a Bridlington scribe in his Gesta Edwardide Carnarvan under the title "versus vaticinales" with no attribution of authorship. ${ }^{14}$ Had the "versus vaticinales" with which the chronicler so admiringly amplifies his narrative been associated previously with his own priory or prior at the time he wrote, he surely would have made some mention of the fact. On the other hand, having incorporated the verses into the serious framework of a monastic chronicle, the author may have encouraged or even initiated the popular association of the prophecy with his own Austin priory at Bridlington. ${ }^{15}$

It is not surprising that the prophecy subsequently came to be associated with John Thwenge (d. 1379), the pious prior of Bridlington. Given the prophecy's probable origin and demonstrated popularity in Yorkshire in the late fourteenth century, tradition demanded that it be attributed to an appropriately sanctified author. No political prophecies circulated for long anonymously in the Middle Ages without some attempt being made to foist them on an authoritative figure. From their very origins such utterances were regularly (but rarely correctly) ascribed to the sibyls, Methodius, Gildas, Merlin, Cadwalader, Bede, Thomas à Becket, Saints Bridget and Hildegard, Joachim, and many others whose legendary or actual prominence lent great rhetorical force to those partisan political proph-

10/British Museum MS Cotton Domitian A IX; Bodleian MSS Digby 89 and Bodley 851; Bibliothèque National, Paris MS Fonds Latin 15082.

11/British Museum MSS Royal 8C XVII and Cotton Titus D XII.

12/British Museum MSS Cotton Domitian A IX and Royal 8C XVII; Westminster MS CA 27; Bodleian MS Digby 89.

13/James, pp. 53-55.

14/Chronicles of the Reigns of Edward I and Edward II: "Gesta Edwardi de Carnarvan Auctore Canonico Bridlingtoniensi," ed. William Stubbs (Rolls Ser. 76; London, 1883), 2:91-92, 96, 98, 100, 101. 102, 107. Other verses not in the surviving manuscripts of the prophecy are quoted on pp. $45,89,95,98,148$.

15 /Of the manuscripts containing the prophecy, the earliest to associate it with Bridlington is Cambridge University MS Kk.6.16(2096), whose colophon on fol. 153 reads: "Istos versus dixit unus canonicus de Bridlington qui fuit quasi fatuus . . . jacuit in lecto mortali circa annum Domini $\mathbf{M}^{\circ} \mathrm{CCC}^{\mathrm{mu}}$." The manuscript can be dated 1389-1404. 
ecies which circulated under their names. ${ }^{16}$ John Thwenge was the right man in the right place.

Shortly after his death, Thwenge's tomb was said to have been the site of numerous miracles whose fame spread throughout England. Under the year 1389, the chronicler of the Historia Vitae et Regni Richardi II comments:

Eo tempore in Prioratu Canonicorum de Brydlyngton qui est Dioceseos Eboracensis, ad tumbam Johannis, quondam Prioris ibidem, tanta tamque manifesta fiebant miracula, ut pene totam Angliam ducerent in stuporem. De quo ferunt, quod in vita sua super aquas ambulaverit, mortuum suscitaverit, et horreis Domus praedictae tam manifesta quam mirabilia per orationes frugum fecerit incrementa, ut quae vix per mensem familiae putabantur suffectura, prece sua sufficerent toto anno. ${ }^{17}$

Official inquiries were established which aimed at Thwenge's canonization; his body was translated in $1404 .^{18}$ Among those supporting his canonization was Henry IV, who later placed his son under the special patronage of the Yorkshire saint $;^{19}$ Prince Hal himself, while visiting Bridlington in 1407, made an offering of five marks to "Saint John" in fulfillment of a special vow. ${ }^{20}$ By this time, parts of the prophecy were already being used as anti-Lancastrian propaganda. ${ }^{21}$ It is tempting to hypothesize that Yorkist adherents were responsible for first attributing the prophecy to Saint John of Bridlington and then using it as propaganda against the Lancastrian royalty, whose patron thereby became a prophet of their own doom. On the other hand, in spite of Henry IV's scornful dismissal of certain lines of the prophecy, the possibility remains that at some time his own propagandists countered Yorkist claims to the throne with supposedly proLancastrian excerpts from the prophecy which they themselves attributed to their popular northern saint. ${ }^{22}$

At all events, the one reasonably certain conclusion that can be drawn is that there is nothing in the edifying life of the saintly John Thwenge to make us suspect

16/Concerning the tradition of foisting Welsh vaticination on the bard Myrddin (Merlin), see Margaret Enid Griffiths, Early Vaticination in Welsh with English Parallels, ed. T. Gwynn Jones (Cardiff, 1937), pp. 87, 139. For the context in which certain lines of the prophecy were quoted at the trial of Joan of Arc as being the prophetic words of the Venerable Bede, see Procès de condamnation et de réhabilitation de Jeanne d'Arc dite La Pucelle, ed. Jules Quicherat (Paris, 1845), 3:338-39.

17/Historia Vitae et Regni Richardi II Angliae Regis, ed. Thomas Hearne (Oxford, 1729), p. 115.

18/Acta Sanctorum, ed. Jean Carnandet (Paris, 1868), October 10, sec. 5, pp. 137-44. Whether Thwenge was actually canonized remains in some doubt. See also Nova Legenda Anglie, ed. Carl Hortsman (Oxford, 1901), 2:64-78; Analecta Bollandiana, ed. H. Delehaye et al. (Brussels, 1935); Dom David Knowles, The Religious Orders in England (Cambridge, 1961), pp. 117-18; also, John Bale, Index Britanniae Scriptorum, ed. Reginald Poole (Oxford, 1902), pp. 184, 185; John Bale, Illustrium Maioris Britanniae Scriptorum (Ipswich, 1548), fols. 104v-105. The dates given by Bale's article in the Illustrium show that he was thinking of John the tenth prior of Bridlington. John Bale, Scriptorum Illustrium Maioris Britanniae (Basle, 1557-59), 1:623; John Pits, Relationum Historicarum de Rebus Anglicis (Paris, 1619), pp. 667-78; Thomas Tanner, Bibliotheca Britannico-Hibernica (London, 1748), p. 125; Thomas Tanner, Notitia Monastica (London, 1744), p. 649.

19/Peck, p. 113; J. H. Wylie, A History of England under Henry IV (London, 1896), 3:336.

20/Wylie, 3:334.

21/Eulogium Historiarum, 3:391-93.

22/MS Arundel 66 containing a copy of our prophecy is noteworthy in this respect if it was actually executed for Henry VII. See H. L. D. Ward, A Catalogue of Romances in the Department of Manuscripts in the British Museum (London, 1883), 1:301; Fritz Saxl and Hans Meier, A Catalogue of Astrological and Mythological Illuminated Manuscripts of the Middle Ages (London, 1953), 3, pt. 1:89-93. 
that he wrote the very worldly poem which circulated so widely under his name. Once John of Bridlington's name was attached to the work, however, scribes and owners were quick to add the familiar name to their copies of the prophecy. The bibliographer Bale (1495-1563) merely followed the contradictory manuscript evidence as we have seen it, ascribing the work now to John of Bridlington, now to Robert the Scribe. ${ }^{23}$ As will be shown later, Bale's legacy survived well into the nineteenth century.

Robert the Scribe (Robertus Scriba) was thought to be the author of the prophecy for different reasons. Robert ruled as fourth prior of Bridlington during the last quarter of the twelfth century ${ }^{24}$ and, according to Leland, was the author of a number of learned commentaries, among which were one on the Apocalypse and another on the twelve prophets of the Old Testament. ${ }^{25}$ Given the initial association of the prophecy with Bridlington, Robert the Scribe became a natural candidate for authorship. First, his commentaries established his fame as a writer interested in prophecy. Second, among those who took political prophecy seriously, the supposed authorship of John Thwenge (b. 1309) was a manifest chronological absurdity, implying that he uttered the prophecy either in utero or as a lisping babe. Robert the Scribe, however, antedating the events predicted by more than a century, qualified for consideration on the grounds of chronological as well as literary probability. Paul Meyvaert has suggested that "the prophecy was originally composed and circulated under the name of Robert of Bridlington.'26 While his arguments are stimulating, Meyvaert's conclusion should be viewed with great caution. As is now clear, neither the evidence of the earliest manu-

23/Bale's Index attributes the prophecy beginning Febribus infectus to Johannes Canonicus de Bridlington (p. 184). What was thought to be another work beginning Taurus cornutus he ascribes to Robertus Scriba Bridlyngtoniensis, prior quartus. Taurus cornutus are the first two words of a line of verse from Distinction 3, chap. 5. Among the surviving manuscripts containing excerpts of the prophecy beginning with these words are MSS Bodley 623 and 648; British Museum MSS Cotton Vespasian E VII and Harley 6148; Cambridge University MS Kk.1.5(D); Society of Antiquaries of London MS 47. Only Bodley 623 and Cotton Vespasian E VII among these attribute the excerpts to Robert the Scribe. In his later work, Bale dropped all reference to Robert as author of Taurus cornutus.

24/William P. Baildon. Notes on the Religious and Secular Houses of Yorkshire. Yorkshire Archaeological Society, Record Ser., vol. 17 (York, 1895), pp. 18-25.

25/John Leland, Commentarii de Scriptoribus Britannicis (Oxford, 1709), pp. 202-3; Johannis Leland, De Rebus Britannicis Collectanae, ed. Thomas Hearne (London, 1770), 4:35; Bale, Scriptorum, pp. 217-18; Pits, pp. 242-43; Casmirus Oudinus, Commentarius de Scriptoribus Ecclesiae Antiquis (Lipsiae, 1722), 2:1578. Oudinus notes that Robert broke into prophecy himself, not wishing to appear less gifted in art than Joachim and Hildegard (p. 1578).

26/Meyvaert, p. 661. Of the six manuscripts which Meyvaert cites to establish an early tradition of attributing the prophecy to Robert the Scribe, two (Arundel 66 and the manuscript formerly in the Biblioteca Norfolciana) are the same manuscript, as the following note on Arundel 66's flyleaf makes clear: "Soc. Reg. Lond. ex dono H. \& N. R. Howard Norfolciensis." See also E. Bernardus, Catalogi Librorum Manuscriptorum Anglie et Hiberniae in Unam Collecti (Oxford, 1697), 2, pt. 1:75, no. 2964.65. Bernardus's list of contents corresponds exactly with the contents of Arundel 66; he notes, also, that the manuscript was in Greshamn College (cf. Tanner, Bibliotheca, p. 117). Furthermore, Arch. Selden B.8, no. 18 (saec. XVI), contains only a loose English version of 105 lines derived from the Latin prophecy and is probably a copy of British Museum MS Additional 24.848 (saec. XVI) which contains both the Latin prophecy and the English version, as does British Museum MS Lansdowne 122 (saec. XVI). These should not be cited as independent witnesses of an early tradition of attributing the prophecy to Robert the Scribe, since they are neither independent of one another nor in any sense early. Perhaps Thomas Gale's note at the end of the Trinity College, Cambridge, copy of the Bridlington chronicle (see Meyvaert, p. 659) should be viewed in the light of this sixteenth-century notion of authorship. 
scripts nor references to the prophecy by the nearest contemporaries support the assertion that the work was initially thought to be that of either Robert the Scribe or John of Bridlington.

Regarding the manuscripts which ascribe the prophecy to a canon or prior of Bridlington, or merely to "Bridlington," it is quite possible, as I suggested above, that the original copies circulated anonymously and then were associated with Bridlington after 1377 because of the Bridlington chronicler's fondness for the verses. The title "Bridlington" might have referred initially to the chronicler himself, but as the fame of the holy John Thwenge spread, his name was added to that of his priory. Similarly, Robert the Scribe's candidacy was proposed by those scribes with a keen sense of chronological and vaticinal probability. On the other hand, the place-name "Bridlington" may have been regarded generally as a synonym for either John Thwenge or Prior Robert the Scribe, both of whom contributed to the widespread renown of their house.

Finally, consideration must be given to John Ergome. Ergome's name is attached thus in a sixteenth-century heading to Bodleian MS Digby 89 , folio 1: "Johannis Brydlington cum commentariis Johannis Ergome." John Bale also attributed the commentary to Ergome. Bale appears to have seen the entire work firsthand in more than one manuscript, as his notes in the Index Britanniae Scriptorum show, but his sources provided him with two different dates of composition, 1340 and $1490 .{ }^{27}$ In both of his later works, Illustrium Maioris Britanniae Scriptorum and its revision Scriptorum Illustrium Maioris Britanniae, Bale notes that Ergome wrote under Henry VII, ca. $1490 .{ }^{28}$ However, with the publication in 1909 of the catalog of the Austin friars at York, M. R. James proved conclusively that John Ergome was a fourteenth-century figure. His signature appears with the titles master and doctor along with the other friars who witnessed the compilation of the catalog dated September 8, 1372. ${ }^{29}$ Further research by Sister Helen Peck in 1930 and ten years later by Aubrey Gwynn established the broad outlines of Ergome's biography. ${ }^{30}$ The name "Ergome" derives from the now defunct Yorkshire village Argham, located in East Riding, not far from the towns of Thwenge and Bridlington. Association of the Ergome family with the monastery at Bridlington reaches back to the twelfth century; family ties with the Percys, whose virtues are proclaimed in the prophecy, were established through marriage. We find one William de Erghum jointly sharing wardship responsibilities with Humphrey de Bohun (grandfather of the Humphrey to whom our prophecy is dedicated) in 1317. A certain John de Ergome was pardoned at the insistence of the Duke of Lancaster for his part in the Beverly insurrection of 1381-82. Our John Ergome studied at the Oxford convent and possibly at the University of Bologna and was a friar at the Augustinian convent at York, where he became prior on May 25,1385 . The following year he acted as master regent at the studium of the papal court and was appointed magister antiquus in Naples.

27/Bale, Index, pp. 185, 199.

28/Bale, Illustrium, fols. 212-212v; Scriptorum, p. 623.

29/James, p. 9.

30/Peck, pp. 31-42; Gwynn, pp. 128-38; A Biographical Register of the University of Oxford to A.D. 1500, ed. A. B. Emden (Oxford, 1957), 1:644. The details of Ergome's life which follow are largely derived from the above sources. 
More important than Ergome's family associations with the heroes of the prophecy, however, are his literary tastes. In particular, the catalog of the Austin friars reveals that Ergome possessed among his more than 220 volumes what must be considered one of the largest personal libraries of occult literature in the fourteenth century. Among the books of "forbidden pursuits" are to be found no. 362 B, "tractatus de penthagono salamonis," "tractatus ad inclusionem spiritus in speculo," "vinculum salomonis," "tractatus ad habendum loquelam cum spiritu et effectum eternum," "liber rubeus qui aliter dicitur sapientia Nigromancie," "ars notoria nova completa." 31 In addition to many of the standard works on astrology and astronomy, Ergome also possessed a choice collection of prophecies, among which I might note no. $156 \mathrm{C}$, "quedam prophetie Merlnyny [Merlini]"; 32 no. $163 \mathrm{~K}$, "Joachim super apocalipsim"; 33 and no. $361 \mathrm{~A}$, "Ambrosii merlini prophecie," "Joachim de oneribus prophetarum," "multe prophecie de anglia breves," "prophecia Roberti de vsecio," "oraculum cirille [-i] cum exposicione ioachim," "excerpciones prophetie ff. Johannis de rupescissa," and most important, two works entitled "versus cuiusdam canonici de actubus [sic] anglie" and "prophetia canonici, febribus"; plus no. 363 C, "Expositio versuum febribus infectus" - which are, of course, the opening words of The Prophecy of John of Bridlington itself. ${ }^{34}$

Serious consideration of Ergome as author of the prophecy or commentary was long delayed by Bale's notion that Ergome lived ca. 1490. Subsequent bibliographers, including Pits and Tanner, ultimately derived their information about Ergome, including his ca. 1490 date, from Bale's research. ${ }^{35}$ It is not surprising, therefore, that Thomas Wright, the editor of the prophecy, having dated the work ca. 1370 on the basis of internal evidence, was compelled to reject Ergome even as commentator, believing with Tanner that he lived over 100 years later than the earliest manuscripts. ${ }^{36}$

M. R. James's native sleuthing talents, however, enabled him to disentangle Ergome's name from the commentator's own ingenious "occultation." It will be recalled that the commentator conceals his name for three reasons which he enumerates in his prefatory letter to Humphrey of Bohun; he does make the following concession: "si super consequencie notam capud miseracionis velitis adiungere nomen obscurum et obsequium salutare." 37 James commented:

Now the nota consequentiae, or indication of a consequence, is the particle ergo, therefore, and the caput miserationis, the head of mercy, is the letter M, which being conjoined make Ergom. ${ }^{38}$

There can be little doubt, therefore, that John Ergome was the author of the commentary on The Prophecy of John of Bridlington. Was he the author of the prophecy itself? Wright, of course, being the inheritor of Tanner's and ultimately of Bale's mistaken notions about Ergome's dates, thought he had nothing to do

31/James, pp. 54-55.

32/lbid., p. 35.

$33 /$ Ibid. p. 36.

34/lbid., pp. 53-54.

35/Pits. pp. 242-43; Tanner, Bibliothe'a. p. 263. Note that Tanner had consulted Digby 89 at firsthand.

36/Wright. 1:xxix, 123 .

37/Ibid.. p. 123.

38/James, p. 11. 
with either prophecy or commentary. Taylor accepted Wright's authority. Meyvaert admitted Ergome as the commentator but rejected him as maker of the prophecy, believing that his identification of the author as a certain "canonicus regularis" contradicted the "authoritative" attribution to Robert the Scribe. Most scholars, including Peck and Gwynn, have accepted James`s answer:

The view of the situation which commends itself to me as most probable is that Ergome first wrote the prophecy and circulated it anonymously and then issued his commentary upon it. ${ }^{39}$

The strongest arguments in favor of Ergome's authorship of the prophecy itself are the following.

Only the author of such an obscure and difficult work could interpret it with the confidence of our seemingly omniscient commentator. Despite Ergome's elaborate preamble on the system of interpreting various of the poem"s "occultations," his actual methodology goes so far beyond the system in sheer ingeniousness as to betray him as the very author of the prophecy itself. Furthermore, a rigorous examination of the commentary will show that, omissions aside, none of Ergome's interpretations can be proved erroneous. One would expect a mere commentator to err occasionally.

The presence in his personal library of two copies of the prophecy alone and one of the prophecy with the commentary might suggest that these copies represent the author's own redactions of his work. The character of those surviving manuscripts which contain the prophecy alone shows that generally such manuscripts contain many more lines than those containing both prophecy and commentary. Ergome's decision to omit certain verses when writing the commentary, it could be argued, is quite consistent with the practice of revision as we know it in all ages.

In line 219 (Distinction 2, chap. 3) the prophet expresses his fear that his words may earn him the wrath of the king's mistress or of the queen herself: "Si modo plus dicam, faciam michi tunc inimicam." Such a statement, naturally, proves the prophecy a fraud, since no prophet while writing would fear the anger of a woman probably yet unborn. More important, however, the commentator himself expresses much the same fear following his gloss on line 623 (Distinction 3 , chap. 11), ${ }^{40}$ and again in his closing remarks to Humphrey of Bohun:

Rogo, si vestre placuerit reverencie, quod iste liber manibus multorum non tradatur, et si secretioribus aliquotiens contingat ostendi, nomen tamen auctoris occultatur, ne incurram aliorum indignationem propter opus quod vestram tantum curavi honestare dignitatem.$^{41}$

Such a fear on the part of a mere commentator is difficult to explain unless we suppose that he is also the prophet himself. Finally, the commentator consistently uses the word "auctor" to refer to the prophet, while in his closing remarks "auctor" clearly is to be taken as the commentator, John Ergome.

The argument against Ergome's authorship of the prophecy seems equally strong and can be briefly summarized. First, it must be admitted that none of the

\footnotetext{
39/Ibid., p. 12.

$40 /$ " Lector recipiat sicut placet quod de prelatis ecclesie nolo aliqua mala inferre."

41/Wright. 1:215. The quotes from the prophecy and commentary in my paper are derived from Bodleian MS Digby 89 , which is the copy text for my critical edition.
} 
evidence used to identify the prophet with the commentator is conclusive. Second, we know of a certain number of ostensibly genuine lines of the prophecy in manuscripts independent of the commentary. ${ }^{42}$ Now, Ergome may have edited out these lines in writing his commentary, yet the possibility remains that he never knew of them and hence could not be their author. Furthermore, the pedantic commentator on The Prophecy of John of Bridlington is usually eager to display his surprisingly (and perhaps suspiciously) intimate knowledge of the sources of the prophet's inspiration; he notes where the verses echo Horace, the Psalms, the Book of Daniel, the Apocalypse, Peter Comestor, and so on; he neglects no opportunity apparently to elucidate the prophecy's profound "erudition." In one instance, however, Ergome passes over a line borrowed verbatim from Avianus's fable entitled "De cancro et matre eius" ("Curva retro cedens dum fert vestigia cancer" [Distinction 3, chap. 1]). If further research indicates that Ergome neglected to identify a considerable number of borrowed lines, we would be justified in crediting him with insufficient knowledge of the verses to have composed them. Finally, assuming the identity of the prophet and the commentator, one would expect to find in the poem as tantalizing a clue to the poet's identity as Ergome has taken pains to leave in his own commentary. The opposite is true. The poem observes strict silence in regard to the identity of its author.

I have attempted to suggest reasons, based on a thorough examination of all the surviving manuscripts and contemporary references to the work, why the early anonymous versions of the prophecy were supplanted by those attributing the work to "Bridlington" and subsequently to John Thwenge and Robert the Scribe. I have also tried to indicate the survival of these early traditions in later manuscripts and in the work of bibliographers whose partial knowledge of the manuscript evidence led them to favor a particular candidate for author. Ergome himself identified the author "secundum communem opinionem vulgi" as a canon regular who composed the prophecy between the years 1307 and $1321 .{ }^{43}$ It seems doubtful that he shared any responsibility for attributing the work to John of Bridlington or Robert the Scribe. After all, being a collector and astute student of political vaticination, Ergome was doubtless aware that, as its reputation spread, popular opinion and circumstance were sure to invent an author whose reputation would lend respectability and authority to an otherwise rather bombastic exercise in blustering chauvinism. Until new evidence is discovered, the identity of the author of The Prophecy of John of Bridlington will remain uncertain. What is important for us to realize, however, is that the attributions which we have in the case of such inflammatory political poetry arise out of particular historical and literary contexts and respond to polemical exigencies having little to do with truth or even probability.

42/See Meyvaert, p. 663, n. 37. A complete survey of all the manuscripts of the prophecy shows a total of thirty-one lines not present in Wright's edition; these additional lines are fully cataloged in Michael $\mathbf{J}$.

Curley, ed., "Versus Propheciales, Prophecia Johannis Bridlingtoniensis (The Prophecy of John of

Bridlington), an Edition" (Ph.D. diss., University of Chicago, 1973), pp. 279-317.

43/Wright, 1:125, 132. 